\title{
EFFECT OF CHILD GROWTH AND DEVELOPMENT TRAINING ON THE KNOWLEDGE AND ATTITUDE AMONGCOMMUNITY HEALTH WORKERSIN SEMARANG, CENTRAL JAVA
}

\author{
Diah Rahayu Wulandari, Dea Amarilisa Adespin, Arwinda-Nugraheni, \\ Ani Margawati, Hari Peni Julianti, Teddy Wahyu Nugroho
}

Department of Public Health, Faculty of Medicine, Universitas Diponegoro

\begin{abstract}
Background: Measuring and monitoring a child's growth is important to judge the adequacy of diets or supplementary food being given. Monitoring child's development is critical to find out if a child's development is on track. It is important to act early if there are signs of potential development delay because early treatment is so important for improving a child's skills and abilities. This study aimed to determine effect of child growth and development training on the knowledge and attitude among community health workers in Semarang, Central
\end{abstract} Java.

Subjects and Method: This study was a quasi-experimental with pretest and posttest with no control design conducted at Rowosari Puskesmas (community health center), Semarang, Central Java. The study subjects involved 62 community health workers (CHWs). The dependent variables were knowledge and attitude about child growth and development. The independent variable was training on how to measure and monitor child growth and development. The data were collected by questionnaire, and analyzed by Wilcoxon test.

Results: Knowledge was higher after training (Mean= 77; $\mathrm{SD}=9.8)$ than before (Mean=68; $\mathrm{SD}=11.2)$, and it was statistically significant $(\mathrm{p}=0.001)$. Attitude was higher after training (Mean $=80 ; \mathrm{SD}=12.8)$ than before $(M e a n=70 ; \mathrm{SD}=10.1)$, and it was statistically significant $(\mathrm{p}=0.001)$.

Conclusion: Training is effective in improving knowledge and attitude about child growth and development monitoring among CHWs.

Keywords: knowledge, attitude, growth,development, monitoring, children, community health workers.

\section{Correspondence:}

Diah Rahayu Wulandari. Department of Public Health, Faculty of Medicine, Universitas Diponegoro, Jl. Prof. H. Soedarto, SH., Tembalang, Semarang, Central Java. Email: wulwul2001@gmail.com. Mobile: 08995583551 